\title{
Flunisolide nasal spray for perennial rhinitis in children
}

\author{
J K SARSFIELD, G E THOMSON
}

beclomethasone dipropionate pulmonary aerosol (4), and corticosteroid creams (3). Seventeen had used a beclomethasone dipropionate nasal spray, but only five had obtained a "good" response.

The active agent contained flunisolide as an aqueous propylene glycol solution $\left(0.025^{\circ}, \mathrm{o} / \mathrm{v}\right)$ and was supplied in glass bottles fitted with a mechanical pump spray delivering $0.1 \mathrm{ml}$ per actuation. The placebo consisted of the vehicle alone in identical bottles. The study had a double-blind, cross-over design. On admission the children were allocated at random to one of two groups. One received the active nasal spray for four weeks followed by four weeks with the placebo spray, and the other the same treatment but reversed. They were instructed to use one spray up each nostril three times daily at about eight-hour intervals. For patients using the active spray this provided a total daily dose of $150 \mu \mathrm{g}$.

After the double-blind trial children who had obtained benefit from flunisolide were invited to continue using the spray for six months, an open assessment of any symptoms and side effects being made at two-month intervals. The older children had blood cortisol concentrations measured in samples taken at 0900 . All children could reduce the frequency of sprays from three times to twice or once daily provided satisfactory control was maintained. study period. Many reduced the dosage from three times to twice or once daily without losing benefit. The effect of flunisolide on the pituitary-adrenal axis was assessed in seven children by measuring the 0900 blood cortisol concentrations at two-month intervals over the six months. No effect was observed.

The results show that flunisolide is effective and safe for the treatment and prophylaxis of perennial rhinitis in children.

\section{Introduction}

Perennial rhinitis is common in childhood and impairs the quality of life. Complications include speech problems and hearing loss, and many patients suffer unwanted effects of symptomatic drug treatment. The condition has an allergic aetiology in most cases, but avoidance regimens are seldom successful. Topical treatment with beclomethasone dipropionate may be used safely for prophylaxis against seasonal and perennial rhinitis in children, ${ }^{12}$ though some fail to derive benefit. rlunisolide, a new steroid with good topical activity, is safe and effective in adults ${ }^{3-6}$ and may be of value in children. ${ }^{78} \mathrm{We}$ have therefore assessed the efficacy of flunisolide nasal spray in a group of children with perennial rhinitis.

\section{Patients and methods}

Twenty-seven children with clinical evidence of perennial allergic rhinitis entered the study. Twenty-one were boys and six girls, and their ages ranged from 7 to 16 years (mean age 12.3 years). The mean duration of disease was 7.4 years. All had been tested by skin-prick with various common allergens and shown a positive reaction to at least one, the most common response being to the house-dust mite. Eighteen children $(67 \%)$ had a family history of allergic disease, and $19\left(70^{\circ} \circ\right)$ had one or more other allergic problems, usually asthma. None of the children was taking oral corticosteroids or using any local nasal treatment at the start of the trial. Drugs regularly used for other concurrent illnesses were sodium cromoglycate inhalations ( 1 patient),

Harrogate General Hospital, Harrogate HG2 7ND

J K SARSFIELD, MD, MRCP, consultant paediatrician G E THOMSON, MB, BS, senior house officer

\section{LABORATORY INVESTIGATIONS}

At each visit to the clinic blood samples were taken for measurement of haemoglobin concentration and absolute and differential white cell counts. Nasal swabs were taken for fungal culture and to enable smears for eosinophil quantification to be made.

\section{Results}

One child withdrew during the placebo period because of nasal irritation. Table I gives the means of weekly symptom recorded in the diary cards. In most cases (14 out of 16 pairs of means) the symptoms were less during flunisolide treatment than during the corresponding period of placebo treatment. Table II lists the changes in symptom scores from baseline admission values as assessed by the physician. On admission the two treatment groups had similar scores, and in general these were reduced by both flunisolide and placebo. Flunisolide, however, produced large reductions in scores more often than placebo. The improvement in scores was statistically significant for sneezing (in both treatment groups), stuffiness, postnasal drip, and 
throat itch. All these changes were recorded after treatment with flunisolide.

Table III shows the patients' rating of overall control of symptoms after each treatment period. After flunisolide 21 of the 26 patients thought that they had derived benefit, whereas after placebo only six patients thought this. When each patient's responses to flunisolide and placebo were compared, flunisolide was found to provide a significantly higher degree of control of symptoms than placebo $(\mathbf{P}<0.001$; Wilcoxon signed rank test).

On completing the study 20 patients thought that the flunisolide period was more effective, four preferred the placebo period, and two rated the periods equally. Similarly, the physician's preference was for flunisolide in 20 cases, for placebo in three, and equal in the other three. These preferences favouring flunisolide were significant $(P<0.002)$.

TABLE I-Means of weekly symptom scores recorded in diary cards

\begin{tabular}{|c|c|c|c|c|c|}
\hline \multirow{2}{*}{ Symptom } & \multirow{2}{*}{ Treatment - } & \multicolumn{4}{|c|}{ Mean weekly symptom score* } \\
\hline & & 1 & 2 & 3 & 4 \\
\hline $\begin{array}{l}\text { Sneezing } \\
\text { Stuffy nose }\end{array}$ & $\begin{array}{l}\cdots\left\{\begin{array}{l}\text { Flunisolide } \\
\text { Placebo } \\
\text { Flunisolide }\end{array}\right. \\
\text { Placebo } \\
\cdots\left\{\begin{array}{l}\text { Flunisolide } \\
\text { Placebo }\end{array}\right. \\
\text { Flunisolide } \\
\text { Placebo }\end{array}$ & $\begin{array}{l}0.96 \\
0.86 \\
1.12 \\
1.22 \\
0.55 \\
0.97 \\
1.00 \\
1.35\end{array}$ & $\begin{array}{l}0.79 \\
1.18 \\
0.81 \\
1.25 \\
0.59 \\
1.02 \\
0.84 \\
1.47\end{array}$ & $\begin{array}{l}0.65 \\
1.23 \\
0.62 \\
1.17 \\
0.58 \\
0.92 \\
0.86 \\
1.48\end{array}$ & $\begin{array}{l}0.64 \\
1.17 \\
1.04 \\
1.00 \\
0.62 \\
0.85 \\
1.10 \\
1.45\end{array}$ \\
\hline
\end{tabular}

*Symptom scores: 0 none, 1 mild, 2 moderate, 3 severe.

Eight side effects were reported by eight patients while using the active spray and 12 side effects by 10 patients while using placebo. These were irritation of the upper airways ( 15 cases), eye-watering (4), and abdominal discomfort (1). The upper respiratory tract irritation was usually mild and transient, though it resulted in one patient stopping treatment with placebo after two weeks.

Laboratory investigations showed no significant changes in haemo-
$95 \mathrm{nmol} / \mathrm{l}(3.4 \mu \mathrm{g} / 100 \mathrm{ml})$. Inquiry showed that he had taken four $0.5-\mathrm{mg}$ tablets of betamethasone (Betnesol) over the previous two days for an asthma attack. Repeat cortisol measurement 10 days later, and subsequent routine estimations while continuing with flunisolide, were all normal.

The open subjective assessment showed no decline in symptom control. This satisfactory control was maintained in seven children who reduced the dose frequency to twice daily and five who reduced to a once-daily treatment. These reductions were usually made around mid-study. Ten children reported no side effects, four had transient nasal stinging, and two experienced mild, intermittent headache.

\section{Discussion}

This study showed the value of flunisolide in perennial rhinitis in children. Side effects were few and the spray was generally well tolerated. No interference with the pituitaryadrenal axis was detectable when using the therapeutic dose. The results concur with the reported efficacy and safety of flunisolide in perennial rhinitis in adults. ${ }^{5}$ Our study showed better control of symptoms with flunisolide, which may reflect the greater likelihood of an allergic aetiology in children. Other studies suggest that patients with a demonstrable allergic component to their disease respond better than those with non-allergic rhinitis, ${ }^{10}$ but this has been disputed. ${ }^{11}$

Nasal irritation was the commonest side effect. It was probably due to the vehicle solution acting on hypersensitive airways, as it occurred more often during the placebo period. This transient irritation may be offset by the anti-inflammatory effect of the steroid contained in the active spray. The choice of vehicle, however, enables metered doses to be delivered by a pump spray and avoids the need for halogenated hydrocarbon propellants.

The value of corticosteroids in allergic rhinitis is well established, and their systemic use may be justified for the shortterm treatment of hay fever. The dangers from long-term systemic treatment with corticosteroids forbids their use in

TABLE II-Physician's assessment of changes in symptom scores $\dagger$ from baseline (admission) values

\begin{tabular}{|c|c|c|c|c|c|c|c|c|c|}
\hline \multirow{2}{*}{\multicolumn{4}{|c|}{ Symptom }} & \multirow{2}{*}{$\begin{array}{l}\text { Mean symptom } \\
\text { score on } \\
\text { admission } \dagger \pm S D\end{array}$} & \multicolumn{2}{|c|}{ Mean change $\pm \mathrm{SD}$} & \multirow{2}{*}{$\begin{array}{l}\text { Mean symptom } \\
\text { score on } \\
\text { admission } \dagger \pm S D\end{array}$} & \multicolumn{2}{|c|}{ Mean change $\pm \mathrm{SD}$} \\
\hline & & & & & $\begin{array}{l}\text { First } 4 \text { weeks on } \\
\text { flunisolide }\end{array}$ & $\begin{array}{l}\text { Second } 4 \text { weeks on } \\
\text { placebo }\end{array}$ & & $\begin{array}{c}\text { First } 4 \text { weeks on } \\
\text { placebo }\end{array}$ & $\begin{array}{l}\text { Second } 4 \text { weeks on } \\
\text { flunisolide }\end{array}$ \\
\hline $\begin{array}{l}\text { Sneezing .. } \\
\text { Stuffiness .. } \\
\text { Runny nose } \\
\text { Nose-blowing. } \\
\text { Postnasal drip } \\
\text { Epistaxis .. } \\
\text { Throat itch }\end{array}$ & $\begin{array}{l}\ldots \\
\cdots \\
\cdots \\
\cdots \\
\cdots\end{array}$ & $\begin{array}{l}\ldots \\
\ldots \\
\cdots \\
\cdots \\
\cdots\end{array}$ & $\begin{array}{l}\ldots \\
\cdots \\
\cdots \\
\cdots \\
\cdots\end{array}$ & $\begin{array}{l}1 \cdot 86 \pm 0.86 \\
2 \cdot 14 \pm 1 \cdot 10 \\
0.71 \pm 0.73 \\
1 \cdot 14 \pm 1 \cdot 10 \\
1.64 \pm 1 \cdot 01 \\
0.43 \pm 0.76 \\
0.21 \pm 0.43\end{array}$ & $\begin{array}{c}-1.57 \pm 0.85^{* * *} \\
-1.36 \pm 1.45^{* *} \\
-0.07 \pm 1.02 \\
0.14 \pm 1.51 \\
-1.00 \pm 1.24^{*} \\
-0.43 \pm 0.76 \\
0.0 \pm 0.78\end{array}$ & $\begin{array}{r}-0.64 \pm 1.22 \\
-0.64 \pm 1.39 \\
0.57 \pm 1.02 \\
0.43 \pm 1.28 \\
-0.79 \pm 1.31 \\
-0.36 \pm 0.84 \\
0.0 \pm 0.68\end{array}$ & $\begin{array}{l}1.85 \pm 0.90 \\
2.08 \pm 0.76 \\
1.46 \pm 1.27 \\
2.15 \pm 1.07 \\
1.31 \pm 1.03 \\
0.61 \pm 0.77 \\
0.69 \pm 0.75\end{array}$ & $\begin{array}{l}-0.42 \pm 1.00 \\
-0.67 \pm 1.23 \\
-0.25 \pm 1.29 \\
-0.33 \pm 0.98 \\
-0.25 \pm 1.05 \\
-0.42 \pm 1.00 \\
-0.50 \pm 0.67\end{array}$ & $\begin{array}{l}-0.83 \pm 1.27 * \\
-0.92 \pm 1.50 \\
-0.50 \pm 1.51 \\
-0.75 \pm 1.21 \\
-0.25 \pm 0.87 \\
-0.50 \pm 1.00 \\
-0.58 \pm 0.51^{*}\end{array}$ \\
\hline
\end{tabular}

Significance of change from score on admission: ${ }^{*} \mathrm{P}<0.05 ;{ }^{*} \mathrm{P}<0.01 ;{ }^{* *} \mathrm{P}<0.001$. (Wilcoxon signed rank test.)

† Symptom scores: 0 none, 1 mild, 2 moderate, 3 severe.

globin concentration or blood eosinophil count. Although flunisolide produced a greater reduction in nasal eosinophils than did placebo, the difference was not significant. Cultures for nasal candida yielded scanty growth in two patients, one of whom was using placebo and one flunisolide. Neither infection was clinically apparent or required treatment.

Seventeen children were enrolled in the six-month follow-up study. One defaulted at three months, although he had no history of side effects. Of the 16 completing the six months, seven had their 0900 blood cortisol concentrations measured at two-month intervals. In six of these seven patients the four individual values did not fall below the normal range ${ }^{9}(138-497 \mathrm{nmol} / 1 ; 5-18 \mu \mathrm{g} / 100 \mathrm{ml})$. In one child the blood cortisol concentration at the two-month visit was found to be

TABLE III-Subjective assessment of overall control after each four-week treatment period (figures are numbers of patients)

\begin{tabular}{lccccc}
\hline Sympton control: & Total & Good & Minor & None & Worse \\
\hline After flunisolide & 4 & 9 & 8 & 4 & 1 \\
After placebo & 0 & 3 & 3 & 14 & 6
\end{tabular}

perennial rhinitis, especially in childhood. Early attempts to control symptoms by topical application of steroids such as dexamethasone showed that this drug could cause adrenal suppression. ${ }^{12}$ This major side effect has not occurred with the topical nasal application of beclomethason dipropionate. The clinical value of this drug is established, but failure may occur. Interestingly, 17 of the children in our study had used beclomethasone dipropionate but only five had obtained a good response. Hence properly controlled comparative studies are needed.

Our results confirm the reported safety of flunisolide. ${ }^{3} 588$ Its failure clinically to affect pituitary adrenal function was probably due to the low dose used and to the rapid metabolism of any systemically absorbed drug to inactive metabolites by the liver. The six-month monitoring of endogenous cortisol concentrations showed no evidence of adrenal suppression. A further interesting observation was the positive placebo response. We consider that this underlines the need for double-blind studies of drug effectiveness in children, in whom subjective responses may be as misleading as in adults. 
We thank Dr P C N Clarke, Dr C W Jones, Dr C Engler, and Mrs $S$ Reid for their help.

\section{References}

1 Prahl, P, Wilken-Jensen, K, and Mygind, N, Archives of Disease in Childhood, 1975, 50, 875 .

2 Shore, S C, and Weinberg, E G, Archives of Disease in Childhood, 1977, $52,486$.

3 Turkeltaub, P D, Norman, P S, and Crepea, S, fournal of Allergy and Clinical Immunology, 1976, 58, 597.
4 Bloom, F L, et al, Annals of Allergy, 1977, 38, 408.

5 Schulz, J I, Johnson, J D, and Freeman, S O, Clinical Allergy, 1978, 8, 313.

${ }^{6}$ Sahay, J N, Chatterjee, S S, and Engler, C, Clinical Allergy, 1979, 9, 17.

7 Strem, E L, Austrian, S, and Geller, G, fournal of Allergy and Clinical Immunology, 1978, 61, 150

8 Siegal, S, et al, fournal of Allergy and Clinical Immunology, 1978, 61, 152.

9 Wood, B, A Paediatric Vade-Mecum, p 129. London, Lloyd-Luke, 1974

${ }^{10}$ Morrison Smith, J, et al, British Medical fournal, 1975, 2, 255.

11 Tarlo, S M, et al, fournal of Allergy and Clinical Immunology, 1977, 59, 232

12 Norman, P S, et al, fournal of Allergy and Clinical Immunology, 1967, 40, 57.

(Accepted 26 May 1979)

\title{
Anti-keratin antibodies in rheumatoid arthritis
}

\author{
B J J YOUNG, R K MALLYA, R D G LESLIE, C J M CLARK, T J HAMBLIN
}

British Medical fournal, 1979, 2, 97-99

\section{Summary and conclusions}

A naturally occurring antibody that reacts with the keratinised tissue of animal oesophagus was found in the serum of 75 out of 129 patients (58\%) with classical or definite rheumatoid arthritis (RA) but not in sera from 105 healthy people.

Detection of the antibody, which is unrelated to rheumatoid factor, is more specific for $R A$ than the reaction in the sheep-cell agglutination test but less sensitive.

\section{Introduction}

Naturally occurring anti-keratin antibodies (AKA) in human sera were first noted in this laboratory by R S Lloyd in 1970 (unpublished data) using rat oesophagus tissue and fluorescent antibody techniques. The keratins are a family of intracellular, fibrous, and highly complex insoluble proteins exhibiting pronounced heterogeneity. Their structure and chemistry has been extensively studied and reviewed. ${ }^{1}$ Their antigenicity was first shown experimentally by Pillemer et al. ${ }^{2}$ Later studies disclosed considerable cross-reactivity between keratins derived from both human ${ }^{3-5}$ and animal ${ }^{6}$ tissues. These differences were partially resolved by Lee et $a l,{ }^{7}$ who isolated four polypeptides from the precursor protein prekeratin. These are designated $A, A^{1}, B$, and $B^{1}$ and form two immunologically distinct families of $A$ and $B$ chains in mixed proportions. Furthermore, antisera raised to $A$ and $B$ chains react with the major structural protein of the epidermis. Although these findings confirm the work of Bauer, ${ }^{3}$ Kemp and Rogers ${ }^{6}$ detected no such antigenic relation with keratins derived from differentiating cortical cells.

\footnotetext{
Departments of Immunology and Medicine, Royal Victoria Hospital, Bournemouth, Dorset BH1 4JG

B J J YOUNG, MSC, FIMLS, senior chief medical and laboratory scientific officer

R K MALLYA, MB, MRCP, medical registrar (present address: Department of Medicine, Bristol Royal Infirmary, Bristol BS2 8HW)

R D G LESLIE, MB, MRCP, medical registrar (present address: King's College Hospital, London SE5 9RS)

C J M CLARK, MD, FRCP, consultant physician

T J HAMBLIN, MRCP, MRCPATH, consultant haematologist
}

We now think that the antigenic specificity of the keratin molecule may be modified by reorganisation of the $A$ and $B$ chains during the keratinisation process itself ; this is discussed by B J J Young (paper in preparation). Preliminary testing for AKA was carried out on 10589 sera from patients being investigated with standard autoantibody tests for a wide variety of medical diseases and on whom adequate clinical data were not available. AKA were found in 552 . The finding that 380 of these sera also produced a positive reaction in the sheep-cell agglutination test (SCAT) (table I) led to the present investigation.

We record here accumulated evidence of the prevalence of AKA in human serum, and more specifically the serum of patients with rheumatoid arthritis (RA).

TABLE I-Prevalence of anti-keratin antibodies $(A K A)$ and rheumatoid factor (positive sheep-cell agglutination test (SCAT) result) in 10589 serum samples examined over two years

\begin{tabular}{lccccc}
\hline & $\begin{array}{c}\text { AKA- } \\
\text { positive }\end{array}$ & $\begin{array}{c}\text { SCAT- } \\
\text { positive }\end{array}$ & $\begin{array}{c}\text { AKA/ } \\
\text { SCAT- } \\
\text { positive }\end{array}$ & $\begin{array}{c}\text { AKA- } \\
\text { positive/ } \\
\text { SCAT- } \\
\text { negative }\end{array}$ & Total \\
\hline $\begin{array}{c}\text { No }(\%) \text { of sera } \\
\text { examined }\end{array}$ & $552(5 \cdot 2)$ & $1054(10 \cdot 0)$ & $380(3 \cdot 6)$ & $170(1 \cdot 6)$ & $10589(100 \cdot 0)$ \\
\hline
\end{tabular}

\section{Patients and methods}

Three groups of sera were examined for antibodies to rat oesophageal keratin and rheumatoid factor.

Group 1 comprised sera from 129 patients with classical or definite $\mathrm{RA} ; 84$ were women and 45 men, and their ages ranged from 18 to 80 years (mean 57 years). The duration of disease ranged from six months to 35 years (mean 7.5 years).

Group 2 comprised sera from 52 patients with non-rheumatoid diagnoses-namely, ankylosing spondylitis (8), psoriatic arthropathy (9), scleroderma (7), keratoconjunctivitis sicca (10), osteoarthropathy (4), systemic lupus erythematosus (10), and polymyalgia rheumatica

(4). Their ages ranged from 31 to 72 years (mean 59 years).

Group 3 comprised sera from 105 healthy blood donors. These sera served as controls.

Twenty AKA-positive samples from group 1 were also tested against, mouse, monkey, and human oesophageal tissue.

Sera were tested for autoantibodies routinely at a $1 / 10$ dilution. ${ }^{8}$ Freshly prepared cryostat sections were examined by the indirect fluorescent antibody technique ${ }^{9}$ with a fluorescein-labelled antihuman immunoglobulin G (IgG) (Wellcome Reagents Ltd). Unfixed cryostat sections of human skin and hair follicles were similarly treated with selected sera. All sera were screened with RA latex reagent (Hyland Laboratories) and positive sera titrated for rheumatoid factor 